\title{
Speckle-tracking parameters as predictors of left ventricular systolic dysfunction in patients with myocarditis
}

\section{S. V. Cherniuk}

State Institution "National Scientific Centre "Institute of Cardiology named after academician M. D. Strazhesko" of NAMS of Ukraine”, Kyiv

Purpose. To evaluate the prognostic capabilities of speckle-tracking echocardiography for prediction of left ventricular systolic dysfunction persistence after 1 -year follow-up of patients with myocarditis.

Methods. We included 58 patients with acute diffuse myocarditis and left ventricular (LV) systolic dysfunction - LV ejection fraction $(E F) \leq 40 \%$ who underwent examination 3 times: within the 1st month after the disease onset, at 6 - and 12-month follow-up. Transthoracic 2-dimensional echocardiography (EchoCG) and speckle-tracking echocardiography (STE) were performed with the measurement of LV end-diastolic volume index (LV EDVi) and LV EF, longitudinal global systolic strain (LGSS) and strain rate (LGSSr), circumferential global systolic strain (CGSS) and strain rate (CGSSr), radial global systolic strain (RGSS) and strain rate (RGSSr). For better clarity, parameters of longitudinal and circumferential strain were presented in absolute values.

Results. After 12-month follow-up in comparison with the 1st month we observed improvement of LV EF $43.2 \pm 3.1 \%$ vs. $32.2 \pm 2.7 \%$ ( $P<0.02)$, respectively, and decrease of LV EDVi $91.1 \pm 6.6 \mathrm{ml} / \mathrm{m}^{2} \mathrm{vs} .112 .2 \pm 7.2 \mathrm{ml} / \mathrm{m}^{2}(P<0.05)$, respectively. But statistically significant increase of STE parameters in comparison with their values in the 1st month was indicated after only 6-month follow-up: the absolute value of LGSS increased from $5.40 \pm 0.41 \%$ to $8.40 \pm 0.63 \%(P<0.01)$ and the absolute value of CGSS - from $6.60 \pm 0.73$ to $10.40 \pm 0.90 \%$ ( $P<0.01$ ). By the 12th month there was a further increase in the absolute values of these indicators which corresponded to the statistically significant increase in LV EF and reduction in LV EDVi. By the use of binary regression analysis we defined cut-off values for STE parameters, measured within the 1st month of myocarditis onset, that with high sensitivity and specificity could predict LV systolic dysfunction persistence after 12 months: LGSS <8.6 \%, LGSSr $<0.61 \mathrm{~s}^{-1}$ and CGSS $<8.3 \%$.

Conclusions. On the basis of dynamic observation we detected STE parameters that within the $1^{\text {st }}$ month of myocarditis onset could be used for prognostication of LV systolic dysfunction persistence after 1-year follow-up: absolute values of LGSS $<8.6 \%$, LGSSr $<0.61 \mathrm{~s}^{-1}$ and CGSS $<8.3 \%$.

\section{Спеки-трекінг ехокардіографічні параметри як предиктори систолічної дисфункції лівого шлуночка у хворих на міокардит}

\section{С. В. Чернюк}

Мета роботи - оцінити можливості спекл-трекінг ехокардіографії для прогнозування персистенції систолічної дисфункції лівого шлуночка протягом однорічного спостереження пацієнтів із міокардитом.

Матеріали та методи. У дослідження залучили 58 пацієнтів із гострим дифузним міокардитом і систолічною диссрункцією лівого шлуночка (ЛШ) - фрракція викиду (ФВ) ЛШ $\leq 40 \%$, яких обстежили тричі (протягом 1 місяця після початку захворювання, через 6 і 12 місяців спостереження). За допомогою двовимірної ехокардіографії та спекл-трекінг ехокардіографії (СТЕ) усім пацієнтам вимірювали індекс кінцево-діастолічного об'єму (ІКДО) та ФВ ЛШ, величини повздовжньої глобальної систолічної деформації (ПГСД), циркулярної глобальної систолічної дефрормації (ЦГСД), радіальної глобальної систолічної деформації (РГСД) і швидкості ПГСД (ШПГСД), швидкості ЦГСД (ШЦГСД) і швидкості РГСД (ШРГСД). Для більшої наочності параметри СТЕ наведені в абсолютних величинах.

Результати. Через 12 місяців спостереження встановили вірогідний приріст ФВ ЛШ і зменшення ІКДО ЛШ порівняно 3

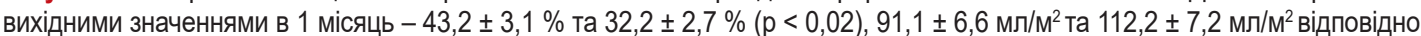
( $p<0,05)$. Однак статистично вірогідне збільшення показників СТЕ визначили вже через 6 місяців спостереження. Так,

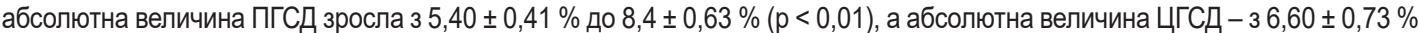
до 10,40 \pm 0,90 \% ( $<$ 0,01). Через 12 місяців тенденція до зростання цих показників СТЕ зберігалась, що відповідало збільшенню ФВ ЛШ і зменшенню розмірів його порожнини. За допомогою бінарного логістичного регресійного аналізу встановили граничні значення для показників СТЕ, що отримали в перший місяць від дебюту міокардиту, за якими можна з високою чутливістю, специфічністю судити про збереження систолічної дисфункції ЛШ (ФВ $\leq 40 \%)$ через 12 місяців спостереження: абсолютні значення ПГСД <8,6 \%, ШПГСД <0,61 c $^{-1}$ і ЦГСД $<8,3 \%$.

Висновки. На підставі динамічного спостереження встановили параметри СТЕ, які протягом першого місяця після початку міокардиту можуть бути використані для прогнозування наявності систолічної дисфуннкції ЛШ через 1 рік спостереження: абсолютні значення ПГСД <8,6 \%, ШПГСД <0,61 $\mathrm{c}^{-1}$ і ЦГСД $<8,3 \%$.
Key words: myocarditis, prognosis, echocardiography.

Zaporozhye medical journal 2018; 20 (4), 471-474 Dol: 10.14739/2310-1210. 2018.4.135543

E-mail: vertebrata@bigmir.net
Ключові слова: міокардит, прогнозування, спекл-трекінг ехокардіографія.

Запорізький медичний журнак. - 2018. T. 20, № 4(109). C. 471-474

\section{Спеки-трекинг эхокардиографические параметры как предикторы систолической Аисфункции левого желудочка у пациентов с миокардитом}

\section{С. В. Чернюк}

Цель работы - оценить возможности спекл-трекинг эхокардиографии для прогнозирования персистенции систолической дисфункции левого желудочка в ходе однолетнего наблюдения пациентов с миокардитом. 
Киючевые слова: миокардит, прогнозирование, спеки-трекинг эхокардиография.

Запорожский медицинский журнал. - 2018. -

T. 20, № 4(109), C. $471-474$

Материалы и методы. В исследование включены 58 пациентов с острым диффузным миокардитом и систолической дисфункцией левого желудочка (ЛЖ) - фракция выброса (ФВ) ЛЖ $\leq 40 \%$, которые проходили обследование трижды (в течение 1 месяца после начала заболевания, через 6 и 12 месяцев наблюдения). С помощью двухмерной эхокардиографии и спекл-трекинг эхокардиографии (СТЭ) всем пациентам измеряли индекс конечного диастолического объема (ИКДО) и ФВ ЛЖ, величины продольной глобальной систолической деформации (ПГСД), циркулярной глобальной систолической деформации (ЦГСД), радиальной глобальной систолической деформации (РГСД) и скорости ПГСД (СПГСД), скорости ЦГСД (СЦГСД) и скорости РГСД (СРГСД). Для большей наглядности параметры СТЭ представлены в абсолютных величинах.

Результаты. Через 12 месяцев наблюдения установили достоверный прирост ФВ ЛЖи уменьшение ИКДО ЛЖ в сравнении с

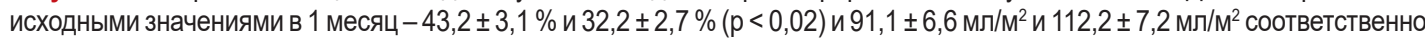
$(\mathrm{p}<0,05)$. Однако статистически достоверное увеличение показателей СТЭ отмечено уже через 6 месяцев наблюдения. Так, абсолютная величина ПГСД выросла с 5,40 \pm 0,41 \% до 8,40 $\pm 0,63 \%$ ( $p<0,01)$, а абсолютная величина ЦГСД - с $6,60 \pm 0,73 \%$ до 10,40 \pm 0,90 \% ( $<$ 0,01). Через 12 месяцев тенденция к росту этих показателей СТЭ сохранялась, что соответствовало увеличению ФВ ЛЖ и уменьшению размеров его полости. С помощью бинарного регрессионного анализа установлены предельные значения для показателей СТЭ, полученных в первый месяц от дебюта миокардита, по которым можно с высокой чувствительностью и специфичностью судить о сохранении систолической дисфуннции ЛЖ (ФВ $\leq 40 \%)$ через 12 месяцев наблюдения: абсолютные значения ПГСД <8,6 \%, СПГСД <0,61 $\mathrm{c}^{-1}$ и ЦГСД <8,3 \%.

Выводы. На основе динамического наблюдения установлены параметры СТЕ, которые в течение 1 месяца после начала миокардита могут быть использованы для прогнозирования наличия систолической дисфункции ЛЖ через 1 год наблюдения: абсолютные значения ПГСД <8,6 \%, СПГСД <0,61 $\mathrm{c}^{-1}$ и ЦГСД <8,3%.

The relevance of myocarditis problem is primarily due to the fact that the disease is more often observed among young people of working age and its severe course can lead to persistent disability, progressive heart failure and death [1-3]. Clinical manifestations of myocarditis are characterized by significant heterogeneity; the disease is distinguished by an unpredictable course of cardiac events and complications, and in many cases necessitates the use of a complex diagnostic approach with high-value diagnostic methods [4,5]. Nevertheless, in modern conditions none of the diagnostic techniques has absolute accuracy, and even an integrated approach to the diagnosis of myocarditis does not always guarantee the correct diagnosis [6-8].

During last years among the novel diagnostic techniques speckle-tracking echocardiography (STE) has established itself as one of the most sensitive for the assessment of myocardial contractile function, particularly in myocarditis and cardiomyopathies $[2,4,6]$. Taking into account the lack of studies related to the myocarditis outcome prediction, our investigation was focused on the detection of STE parameters that could be used for the early prognostication

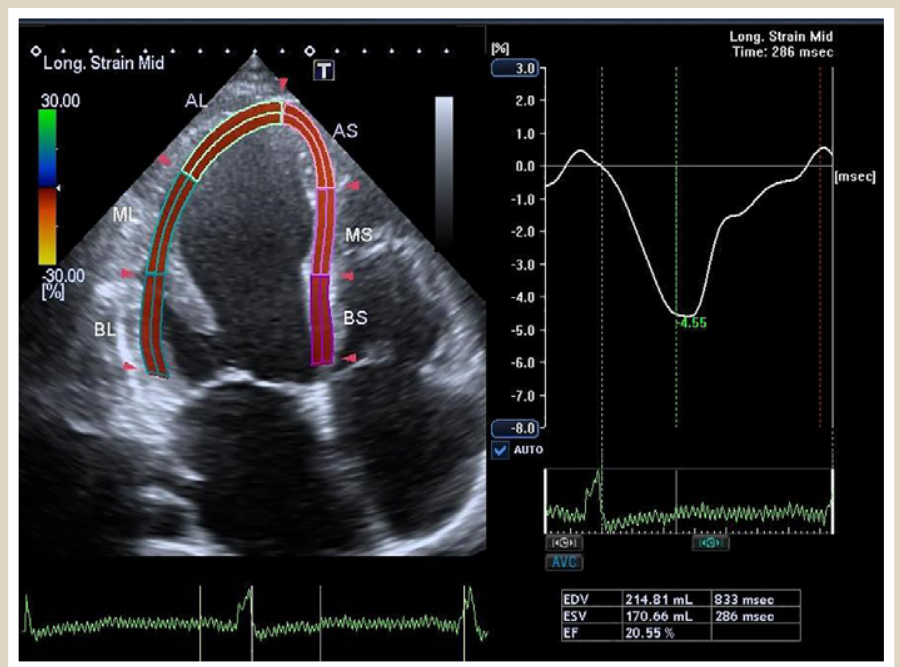

Fig. 1. Impairment of left ventricular global longitudinal strain in patient with acute myocarditis of left ventricular (LV) systolic dysfunction after 1-year follow-up.

\section{Purpose}

To evaluate the prognostic capabilities of speckle-tracking echocardiography for prediction of left ventricular systolic dysfunction persistence after 1-year follow-up of patients with myocarditis.

\section{Materials and methods}

We enrolled 58 patients - 34 males and 24 females with acute diffuse myocarditis and left ventricular (LV) systolic dysfunction - LV ejection fraction (EF) $\leq 40 \%$ in the study. The average age was $38.2 \pm 2.8$ years. All enrolled patients had heart failure (HF) functional class $(\mathrm{FC}) \geq \mathrm{II}$ according to New York Heart Association (NYHA) classification. All patients underwent examinations 3 times: within the 1st month after the disease onset, after 6- and 12-month follow-up. Myocarditis was diagnosed according to the position statement of the ESC Working Group on myocardial and pericardial diseases [7]. The diagnosis of myocarditis was confirmed by cardiac MRI, coronary artery disease was excluded by coronary angiography [8].

Enrolled patients had sinus rhythm and received standard therapies for HF according to the present guidelines which comprised angiotensin-converting enzyme (ACE) inhibitors, comparable doses of beta-blockers, diuretics, mineralocorticoid receptor antagonists [9]. Antiarrhythmic drugs and anticoagulants were used in case of appropriate indications.

Transthoracic 2-dimensional echocardiography (EchoCG) and speckle-tracking echocardiography (STE) were performed on an ultrasound apparatus Aplio Artida SSH -880 CV, Toshiba Medical System Corporation (Japan). LV end-diastolic volume index (LV EDVi) and LV EF were measured in four chamber position by Simpson method [10]. By the use of STE according to recent guidelines we studied LV global systolic deformation parameters: longitudinal global systolic strain (LGSS) and strain rate (LGSSr), circumferential global systolic strain (CGSS) and strain rate (CGSSr), radial global systolic 
strain (RGSS) and strain rate (RGSSr) [10]. For better clarity, parameters of longitudinal and circumferential strain were presented in absolute values, so the closer to zero the parameter value is, the worse contractile function will be.

Statistic processing was performed using Microsoft Office Excel 2007 and SPSS 24.0 software including analysis of Student's test, statistical analysis of contingency tables, binary regression analysis and cut-off values of parameter identification.

\section{Results and discussion}

During the 1st month of myocarditis onset studied patients were characterized by the pronounced impairment of LGSS and CGSS. Fig. 1 and 2 demonstrate STE images with significant decrease in the absolute LGSS and CGSS values in patient with acute myocarditis after 2 weeks since disease onset.

Only after 12-month follow-up in comparison with the 1st month we observed improvement of LV EF $43.2 \pm 3.1 \%$ vs. $32.2 \pm 2.7 \%(P<0.02)$, respectively, and decrease of LV EDVi - $91.1 \pm 6.6 \mathrm{ml} / \mathrm{m}^{2}$ vs. $112.2 \pm 7.2 \mathrm{ml} / \mathrm{m}^{2}(P<0.05)$. But statistically significant increase of STE parameters in comparison with their values in the 1 st month was indicated after only 6-month follow-up: the absolute value of LGSS increased from $5.40 \pm 0.41 \%$ to $8.40 \pm 0.63 \%(P<0.01)$ and the absolute value of CGSS - from $7.70 \pm 0.73$ to $10.40 \pm 0.90 \%(P<0.05)$ (Fig. 3). By the 12th month there was a further increase in the absolute values of these indicators which corresponded to the statistically significant increase in LV EF and reduction in LV EDVi.

Assessment of LGSSr also showed its increase from $0.56 \pm 0.04 \mathrm{~s}^{-1}$ to $0.67 \pm 0.04 \mathrm{~s}^{-1}(\mathrm{P}<0.05)$ and $0.73 \pm 0.05 \mathrm{~s}^{-1}$ $(P<0.01)$ within the 1st month, after 6 - and 12-months follow-up, respectively. These results are consistent with the view of some investigators that STE parameters, particularly LGSS, CGSS and LGSSr, could be even more informative for guiding the management of LV contractile function in patients with myocarditis then LV EF and LV EDVi $[6,11,12]$.

Having the obtained results of dynamic follow-up by statistical contingency tables construction we assessed the role of studied STE parameters, measured within the 1st month, in the presence of LV systolic dysfunction after 12-month follow-up and LGSS, LGSSr as also CGSS were considered as the most significant (Table 1).

Than by the use of binary regression analysis we defined cut-off values for LGSS, LGSSr and CGSS, measured within the 1st month after myocarditis onset that with high sensitivity and specificity could predict LV systolic dysfunction persistence after 12 months (Table 2).

\section{Conclusions}

We suppose that speckle-tracking echocardiography is a highly sensitive visualization technique for guiding the management of patients with myocarditis.

1. Acute diffuse myocarditis within the 1st month after its onset was manifested by pronounced impairment of LV contractile function that was characterized by the marked decrease of LGSS, LGSSr and CGSS. Then after 6- and 12-month follow-up we observed gradual recovery of these indicators which corresponded to the increase in LV EF and

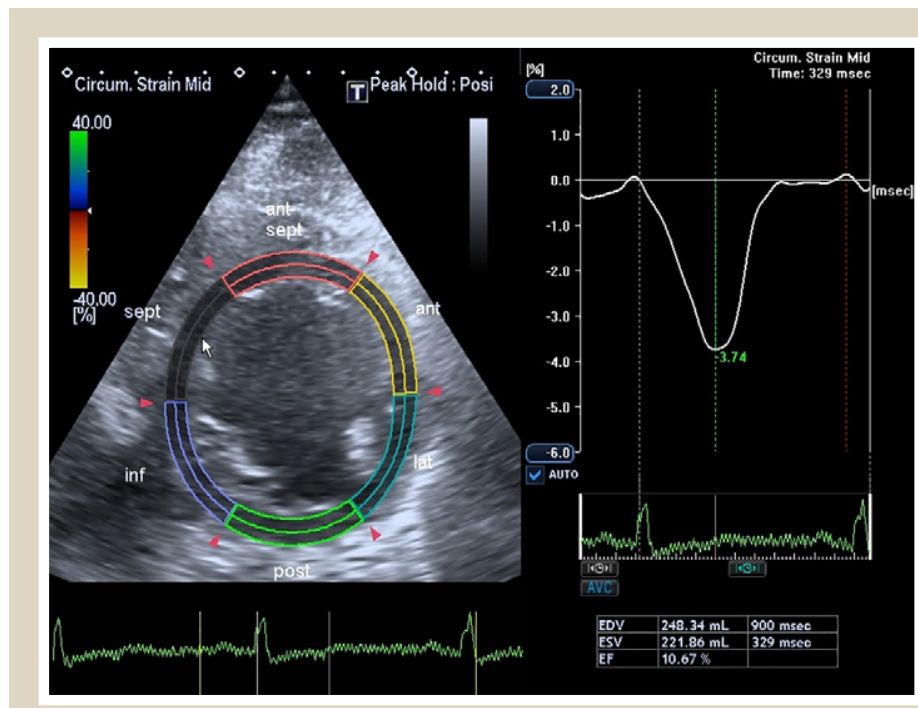

Fig. 2. Impairment of left ventricular global circumferential strain in patient with acute myocarditis

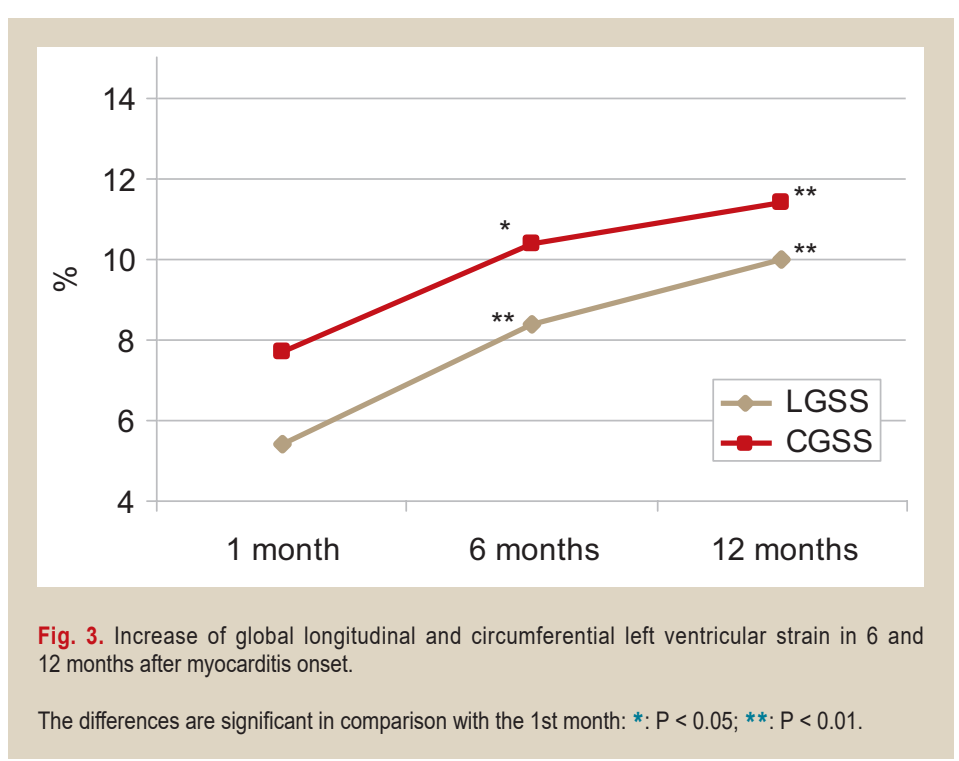

Table 1. The role of speckle-tracking parameters in the presence of left ventricular systolic dysfunction in 12 months after myocarditis onset

\begin{tabular}{l|l|l} 
Parameter & OR & $95 \% \mathrm{Cl}$ \\
\hline LGSS & 3.13 & $1.95-4.71 ; P=0.01$ \\
CGSS & 2.33 & $1.62-3.12 ; P=0.04$ \\
RGSS & 0.65 & $0.64-1.55 ; P=0.07$ \\
LGSSr & 2.71 & $1.82-3.36 ; P=0.02$ \\
CGSSr & 0.88 & $0.91-2.10 ; P=0.06$ \\
RGSSr & 0.61 & $0.70-1.76, P=0.09$ \\
\hline
\end{tabular}

Table 2. The role of speckle tracking parameters as predictors of left ventricular systolic dysfunction in 12 months after myocarditis onset

\begin{tabular}{l|l|l|l}
\hline Parameter & Cut-off value & Sens., \% & Spec., \% \\
\hline LGSS, \% & $<8.6$ & 84 & 68 \\
\hline LGSSr, $^{-1}$ & $<0.61$ & 76 & 78 \\
\hline CGSS, \% & $<8.3$ & 80 & 64 \\
\hline
\end{tabular}


reduction in LV EDVi, but was detected earlier.

2. On the basis of dynamic observation we detected STE parameters that within the 1st month after myocarditis onset could be used for prognostication of LV systolic dysfunction persistence after 1-year follow-up: absolute values of LGSS $<8.6 \%$, LGSSr $<0.61 \mathrm{~s}^{-1}$ and CGSS $<8.3 \%$.

Perspectives of further scientific research include the arrangement of complex studies which could comprise novel visualization techniques in addition to speckletracking, such as cardiac magnetic resonance imaging end positron-emission tomography, for guiding the management of patients with myocarditis.

Conflicts of Interest: author has no conflict of interest to declare.

Конфлікт інтересів: віАсутній.

Information about author:

Cherniuk S. V., MD, PhD, Research Scientist, Department of NonCoronary Heart Diseases and Rheumatology, State Institution National Scientific Centre "Institute of Cardiology named after academician M. D. Strazhesko" of NAMS of Ukraine, Kyiv.

\section{Відомості про автора:}

Чернюк С. В., канА. меА. наук, науковий співробітник відАілу некоронарних хвороб серця та ревматології, АУ „Національний науковий центр «Інститут карАіології імені академіка М. А. Стражеска" НАМН України, м. Київ.

\section{Сведения об авторе:}

Чернюк С. В., канА. меА. наук, научный сотрудник отАела некоронарных болезней сердца и ревматологии, ГУ «Национальный научный центр "Институт карАиологии имени академика Н. А. Стражеско» НАМН Украины, г. Киев.

\section{References}

[1] Elamm, C., Fairweather, D. L., \& Cooper, L. T. (2012). Pathogenesis and diagnosis of myocarditis. Heart, $98(4), 835-840$.

[2] Blessberger, H., \& Binder, T. (2010). Two dimensional speckle-tracking echocardiography: clinical applications. Heart, 96(2), 2032-2040. doi: 10.1136/hrt.2010.199885.

[3] Biestroek, P. S., Beek, A. M., Germans, T., Niessen, H., \& Van Rossum, A. (2015) Diagnosis of myocarditis: current state and future perspectives. Int. J. Cardiol., 191, 211-9. doi: 10.1016/j.ijcard.2015.05.008.

[4] Shauer, F., Gotsman, I., Keren, A., Zwas, D. R., Hellman, Y., Durst, R., \& Admon, D. (2013). Acute viral myocarditis: current concepts in diagnosis and treatment. J. Isr. Med. Assoc., 15, 180-185.

[5] Fung, G., Luo, H., Qin, Y., Yang, D., \& McManus, B. (2016). Myocarditis. Circ. Res., 118(3), 496-514.

[6] Hsiao, J. F., Koshino, Y., Bonninchsen, C. R., Yu, Y., Miller, F. A. Pellica, P. A., et al. (2013). Speckle tracking echocardiography in acute myocarditis. Int. J. Cardiovasc. Imag., 29(2), 275-284. doi: 10.1007| s10554-012-0085-6.

[7] Caforio, A. L. P., Pankuweit, S., Arbustini, E., Basso, C., Gimeno-Blanes, J., Felix, S. B., et al. (2013). Current state of knowledge on aetiology, diagnosis, management and therapy of myocarditis: a position statement of the ESC Working group on myocardial and pericardial diseases. Eur. Heart J., 34(33), 2636-48, 2648a-2648d. doi: 10.1093/eurheartj/eht210.

[8] Friedrich, M. G., Sechtem, U., Schulz-Menger, J., Holmvang, G., Alakija, P., Cooper, L. T., et al. (2009) Cardiovascular magnetic resonance in myocarditis: a Journal of the American College of Cardiology White Paper. J. Am. Coll. Cardiol., 53(17), 1475-1487. doi: 10.1016/j. jacc.2009.02.007.

[9] McMurray, J. V., Adamopoulos, S., Anker, S. D., et al. (2012). ESC Guidelines for the diagnosis and treatment of acute and chronic heart failure. Eur. Heart J., 33, 1787-1847.

[10] Lang, R., Badano, L. P., Mor-Avi, V., Afilalo, J., Armstrong, A., Ernande, L., et al. (2015). Recommendations for cardiac chamber quantification in adults: an update from the American Society of echocardiography and European Asssociation of cardiovascular imaging. J. Am. Soc. Echocardiogr., 28(1), 1-39.e14. doi: 10.1016/j. echo.2014.10.003.
[11] Mornos, C., Rasinara, D., Manolis, A. J., Zacharopoulou, I., Pittaras, A., \& lonac, A. et al. (2011). The value of new speckle-tracking index including left ventricular global longitudinal strain and torsion in patients with dilated cardiomyopathy. Hallenic J. Cardiol., 52(4), 299-306.

[12] Di Beela, G., Coglitore, S., Zimbulatti, C., Minutoli, F., Zito, C., Patane', S., \& Carerj, S. (2008). Strain Doppler echocardiography can identify longitudinal myocardial dysfunction derived from edema in acute myocarditis. Int. J. Cardiol., 126(2), 279-280. doi: 10.1016/j. ijcard.2007.01.110. 